\title{
Parents' Views on the Use of Technology in the Early Childhood Period
}

\author{
Fatma Yaşar Ekici ${ }^{1}$ \\ ${ }^{1}$ İstanbul Sabahattin Zaim University, Education Faculty, Istanbul, Turkey \\ Correspondence: Fatma Yaşar Ekici, Assist. Prof. Dr., İstanbul Sabahattin Zaim University, Education Faculty, Istanbul, \\ Turkey.
}

Received: October 17, 2016

doi:10.11114/jets.v4i12.1925
Accepted: October 31, $2016 \quad$ Online Published: November 3, 2016

URL: http://dx.doi.org/10.11114/jets.v4i12.1925

\begin{abstract}
The main aim of this research is to examine parents' views on technology use in the early childhood period. Survey method was used in this research. The research population consists of the parents, whose children go to the pre-school education institutions in Istanbul province. The research sample consists of 477 parents chosen by the random sampling method, who have children who go to 9 different pre-school education institutions in the 2015-2016 spring semester, 3 of these schools being state schools and 6 private schools. The "Personal Information Form" developed by the researcher and the "Parents' Views on the Use of Technology by Children in the Pre-School Period Scale" developed by Kılınç were used in the data collection. Data collected for the study were analysed using SPSS 20 program. At the end of the research, it was found out that parents' views on the use of technology in the early childhood period differ significantly by the gender of the children, the gender of parents, the type of the school children attend and the level of income, while parents' views on the use of technology in the early childhood period do not differ significantly by the working status of the mothers, the age of the children and the number of children parents have.
\end{abstract}

Keywords: early childhood period, technology use, parents' views

\section{Introduction}

While the early childhood period covers the age of 0-8, the early childhood development involves physical, cognitive, and social developments in the early periods of children's life. This period is the ages when growth and development occur most rapidly (Özmert, 2005). Children become acquainted with technology in the early childhood years, and particularly with information and communication technology (ICT) which can be defined as any kind of visual, audial, printed and written means which ensure access to information and creating information and can use them since the young ages. ICT according to Bolgan (2006) is a concept which involves digital means such as computer, printer, scanner, digital camera, various computer software, telephone, electronic toys, audio hardware and the Internet. While Plowman and Stephen (2005) give the same definition, they also include toys such as telephone, computer, microwave oven which imitate ICTs in this definition. Many studies carried out on ICT in pre-school education focus solely on the children's computer use. However, some studies conducted research by addressing a wider definition of ICT (Plowman and Stephen, 2005; Bolgan, 2006; O'Hara, 2008). Contemporary studies show that the rates of the children's use of ICT increase day by day, that the age at which they become acquainted with ICT decreases and that the applications they use diversify. (Holloway, Green and Livingstone, 2013; The Organisation for Economic Co-operation and Development [OECD], 2011; Radyo Televizyon Üst Kurulu [RTÜK], 2013). Television, camera, computers, smartphones have become a part of the children's lives in our modern society (Akkoyunlu and Tuğrul, 2002).

As well as readily accessing many applications that imitate the games in smartphones, children can also easily access entertainment-purpose TVs, DVD players, music players, computers and the Internet. Furthermore, they can also easily use digital and phone cameras in order to talk to the other members of the family and their relatives (Plowman, McPake and Stephen, 2010). As a result of the study they performed on the Internet usage frequency of pre-school students, Kenanoğlu and Kahyaoğlu (2011) found out that $36,1 \%$ of pre-school students use the Internet every day, $27,8 \%$ use it once a week, $6 \%$ once a month, while $30,1 \%$ do not use the Internet at all. In addition to this, ICT has also started to be used frequently in pre-school education, as well. Many studies have been carried out in Europe and America on the effect of information and communication technologies on pre-school education and their integration into pre-school education. As a result of these studies, technology has been increasingly included in pre-school education as of the 2000s, and various practices have been carried out (Marsh, Brooks, Hughes, Ritchie, Roberts and Wright, 2005; Rideout, 
Vandewater and Wartella, 2003; Kucirkova, Messer, Seehy and Panadero, 2014; Veenstra, van Geert and van der Meulen, 2010; Hansen, 2009; Rasanen, Salminen, Wilson, Aunio and Dehaene, 2009). It is expressed by educators that an ideal time for meeting ICT and giving training on the use of ICT is the pre-school period (Tekcan, 2009). The sense of curiosity of the children in this age group is promoted thanks to ICT, and the possibility to learn by living, trying and error is provided to the children in this age group. For this reason, ICT is used in various fields in pre-school education. For example, ICT is used in such fields as developing exercise skills, cognitive development, counting and mathematics and reading and writing skills, and thus, it becomes easier to give children feedback on their actions (Demir and Kabaday1, 2008).

When used in a suitable manner to the development level of the children in the pre-school period, it positively affects the development of children (Bütün-Ayhan and Aral, 2005). Various positive effects of the use of ICT on pre-school children were also emphasised in the studies regarding the use of ICT in learning-teaching processes. For example, it is expressed that the use of ICT in the pre-school period renders learning more meaningful and enjoyable (Akpinar, 2005; Arı ve Bayhan, 2003), and it develops creative thinking skills (Sivin-Kachala and Bialo, 2000). ICT also enables active learning by individualizing learning when used in pre-school teaching (Küçükoğlu, 2013). One of the purposes of preschool education is to preparing children to elementary school (Milli Eğitim Bakanlığı [MEB], 2013). For this reason, the preparation activities for writing in the pre-school period are carried out. In a study on the use of ICT in the preparation activities in the pre-school period, it was expressed that the use of ICT increases the motivation of students regarding the writing process (Arrowood and Overall, 2004). In other studies on this subject, similar results were achieved and it was expressed that children are more motivated in computer-supported activities (Chung and Walsh, 2006; Talley, Lance and Lee, 1997). The use of technology in the development of social, cognitive and lingual skills of children in pre-school education is regarded as an important tool in learning-teaching processes (Gimbert and Cristol, 2004). It was also shown in the studies carried out that children who use ICT in this period are more successful in mental development, the formation of information, problem-solving skills and lingual skills than those who do not (Clements and Sarama, 2003). Painting and drawing tasks have a significant part in pre-school teaching. These studies are widely used in order to prepare children for writing. It was shown in the studies carried out that children use the same processes with the ones in crayons or pastels when computers and tablets are used in painting and drawing tasks (Matthews and Jessel, 1993), and they increase their interest in painting and drawing (Couse and Chen, 2010; Trepanier-Street, Hong and Bauer, 2001). In his study, İlhan Agan (2004) examined the effect of teaching technology and material-supported foreign language teaching on the learning and memorizing levels of pre-school students. In this study, it was concluded that learning environments in which learning technologies and material-supported teaching are used have positive effects on the success of students. Kumtepe (2006) investigated the effect of the use of a computer on the social skills of pre-school children and found that children with higher computer using skills exhibit less problematic behaviours and have better social skills. In a study, Erdoğan (2009) compared traditional and computer-supported teaching methods in teaching chess in the pre-school period and found that children who are given computer-supported chess education are more successful than children who are given traditional chess education, children participate in the lesson in a more interested way and learn by entertainment during the process of computer-supported teaching. In the study carried out by Çankaya (2012), the effect of using computer games in the process of introducing certain mathematical concepts in the pre-school education period on the level of knowledge of students was examined, and it was concluded that computer games are useful in introducing certain mathematical concepts and the permanence of these concepts in the mind. In a study that aimed to determine the effect of computer-supported teaching on introducing the concepts of time and place to children under six years of age, Kol (2012) concluded that computer-supported teaching is more beneficial in introducing the concepts of time and place. In a study examining the effect of the cartoons, theatre, cinema, Internet games, computer education CDs and TV series on children aged 60-72 months that continue pre-school education, Emir (2011) found that education CDs, theatre, cartoons, and cinema have positive effects on children while Internet games and TV series have negative effects on them. Ayvacı and Devecioğlu (2010) compared computer-supported teaching and the traditional method in the introduction of opposite terms in pre-school children and found that children who are given computer-supported education in the introduction of opposite terms are more successful.

While there are the supporters that the use of ICT by children in the pre-school period is an element of chance in the multi-directional development of children, there are also those who object to it as they regard it as an element of threat. The main reason for this differentiation is directly related to how ICT is used (Şen,2012). While many terms such as digitally local, network generation and millennium generation that express that children can easily use ICT, children face many problems while using ICT (Bartlett and Miller, 2011; Valcke, Bonte, De Wever and Rots, 2010). For example, in addition to many opportunities such as learning, communication, and citizenship, children face problems such as cyberbullying, dependence and violations of privacy (Aslanidou and Menexes, 2008; Chang, 2010; Gasser, Maclay, and Palfrey, 2010). The most important subjects that children may face during the use of ICT are the subjects of health and 
security. For the safety of children, it is necessary to show special care for preventing their exposure to unsuitable content (various games, sexual content, undesirable words) and protecting the privacy of students (Mishra and Joseph, 2012). Siraj-Blatchford and Siraj-Blatchford (2003) emphasised that children's use of computers should be relatively lower when compared to adults, and the duration of computer use should not be more than 40 minutes on average up to 8 years of age. In a report prepared under the editorship of Cordes and Miller (2000), it was asserted that the use of computer at early ages may have various harms on pre-school children in physical, emotional, social, cognitive and moral terms. It was expressed that the eye health of small children who spend time by sitting closely to display applications (TV, computer, game consoles, mobile phones, tablets, laptops, etc.) for a long time will be affected negatively. It was further expressed in this report that sitting in front of the computer for a long time will cause obesity and that various problems may occur in regard to the skeletal structure of the children. It was asserted that such situations as the late development of certain developmental features among children such as the coordination of the sensory organs may occur. In order for ICT to fit the development of children, it is necessary that it has an educational aim, it supports cooperation, that the practices overlap other educational needs, the child is kept under control, the practices are simple as it can be used by the child, there are no applications with violent and sexual content, and it must have been designed with due consideration to the subjects of health and security (Mishra and Joseph, 2012). Almost all of the negativities mentioned about the harms of using ICT in the pre-school period result from the use of ICT unconsciously and in an unguided manner. These problems that generally result from the use of ICT unconsciously and outside the family control in their own houses can be minimized with family supervision again. Rather than prohibiting IT, which children will frequently need in their future lives, teaching how to use it effectively will bring about many benefits. At this point, parents have important duties (Kılınç, 2015). Hence, the responsibilities of parents, who are responsible for the training of their children at the first degree in the pre-school period, further increased with these rapid technologic developments and social changes brought about by these developments (Göğebakan, 2011). In this framework, this study was carried out in order to examine parents' views on technology use in the early childhood period. The sub-objectives determined in line with this main objective are as follows:

- Do the views of parents on the use of technology in the early childhood period differ by the gender of the child?

- Do the views of parents on the use of technology in the early childhood period differ by the gender of the parent?

- Do the views of parents on the use of technology in the early childhood period differ by the working status of the mother?

- Do the views of parents on the use of technology in the early childhood period differ by the type of school which their children attend?

- Do the views of parents on the use of technology in the early childhood period differ by the age of the child?

- Do the views of parents on the use of technology in the early childhood period differ by the number of children that parents have?

- Do the views of parents on the use of technology in the early childhood period differ by the level of income?

\section{Method}

\subsection{Research Model}

Survey method was used in this study as parents' views on the use of technology in the early childhood period are examined. Survey methods are research approaches that aim to describe the past or existing situation as it is (Karasar, 2012).

\subsection{Research Population and Sampling}

The research population consists of the parents, whose children go to the pre-school education institutions in Istanbul province. The research sample consists of 477 parents chosen by the random sampling method, who have children who go to 9 different pre-school education institutions in the 2015-2016 spring semester, 3 of these schools being state schools and 6 private schools.

\subsection{Data Collection Tool}

The "Personal Information Form" and the "Parents' Views on the Use of Technology by Children in the Pre-School Period Scale" were used in the data collection.

Personal Information Form: This form was developed by the researcher in order to obtain information about the demographic properties of the sample. Questions were asked in this form about the age, the type of school the child attend, the gender of the parent, working status of the mother, number of children and the level of income.

The Parents' Views on the Use of Technology by Children in the Pre-School Period Scale: This scale was developed by 
Kılınç (2015) in order to determine the parents' views on the use of technology by children in the pre-school period. The scale consists of 25 items of Likert-type in the form of "totally disagree", "disagree", "indecisive", "agree" and "totally agree", and 6 dimensions as "Family Guidance in Technology Use", "Benefits of the Technology", "Technology Application Areas", "Harms of the Technology", "Skill of Using Technologic Devices" and "Suggestions". The reliability and validity studies of the scale were again carried out by Kılınç (2015). As a result of the internal consistency analyses carried out, for each dimension of the scale, the Cronbach's Alpha internal consistency coefficients were found as .64 for the dimension of Family Guidance in Technology Use, .74 for the dimension of the Benefits of the Technology, .78 for Technology Application Areas, .67 for the dimension of the Harms of the Technology, .65 for the Skill of Using Technologic Devices, and .75 for the dimension of Suggestions. It was determined that the Cronbach's Alpha internal consistency coefficient for the whole scale is .73 (Kılınç, 2015). That the reliability coefficient is .70 and higher in social sciences is regarded as generally sufficient for the reliability of the test scores (Büyüköztürk, 2011).

\subsection{Data Collection}

Data on the research were gathered in the 2015-2016 spring semester with the help of the directors and teachers in 9 pre-school education institutions. The "Personal Information Form" and the "Parents' Views on the Use of Technology by Children in the Pre-School Period Scale" were reached to the parents by means of the teachers, and it was again collected by the teachers after they had been filled in.

\subsection{Data Analysis}

Data collected for the study were analysed using SPSS 20 program. The One-Way Variance Analysis (ANOVA), Scheffe's Test, Tamhane's T2 Test, Kruskal-Wallis H Test, Independent Group t-Test and Mann-Whitney U Test were used in the analysis of the data.

\section{Findings}

The findings obtained from the study are tabulated below in the framework of sub-objectives.

\subsection{Findings on the First Sub-objective}

The first sub-objective of the study aims to determine whether the views of the parents on the use of technology in the early childhood period differ by the gender of the child. Below, there are findings on the first sub-objective in the form of a table.

Table 1. Independent Group t-Test results carried out in order to determine whether the sub-scale scores of the Parents' Views on the Use of Technology by Pre-School Period Children Scale differ by the gender of the child

\begin{tabular}{|c|c|c|c|c|c|c|c|c|}
\hline \multirow[t]{2}{*}{ Sub-dimension } & \multirow{2}{*}{$\begin{array}{l}\text { Gender } \\
\text { of the } \\
\text { Child }\end{array}$} & \multirow[t]{2}{*}{$\mathrm{N}$} & \multirow[t]{2}{*}{$\overline{\mathrm{X}}$} & \multirow{2}{*}{$\begin{array}{l}\text { Standart } \\
\text { Deviation }\end{array}$} & \multirow{2}{*}{$\begin{array}{l}\text { Standart } \\
\text { Error } \\
\text { Mean }\end{array}$} & \multicolumn{3}{|l|}{ t-Test } \\
\hline & & & & & & $\mathrm{t}$ & $\mathrm{df}$ & $\mathrm{P}$ \\
\hline Guidance & Female & 245 & 19.27 & 2.873 & .184 & & & \\
\hline Technology Use & Male & 232 & 19.25 & 2.776 & .182 & .091 & 475 & .928 \\
\hline \multirow[t]{2}{*}{ Benefits of the Technology } & Female & 245 & 15.69 & 4.421 & .282 & & & \\
\hline & Male & 232 & 15.39 & 4.768 & .313 & .707 & 475 & .480 \\
\hline \multirow[t]{2}{*}{ Technology Application Areas } & Female & 245 & 7.89 & 3.141 & .201 & & & \\
\hline & Male & 232 & 7.59 & 3.294 & .216 & 1.030 & 475 & .304 \\
\hline \multirow[t]{2}{*}{ Harms of the Technology } & Female & 245 & 16.47 & 3.450 & .220 & & & \\
\hline & Male & 232 & 16.25 & 4.016 & .264 & .628 & 475 & .530 \\
\hline Skill of Using Technologic & Female & 245 & 12.31 & 2.599 & .166 & & & \\
\hline Devices & Male & 232 & 12.31 & 2.565 & .168 & -.002 & 475 & .999 \\
\hline \multirow{2}{*}{ Suggestions } & Female & 245 & 9.83 & 1.784 & .114 & & & \\
\hline & Male & 232 & 9.49 & 1.927 & .127 & 2.034 & 475 & $.043 *$ \\
\hline
\end{tabular}

Upon examining Table 1, it is seen that no statistically significant difference was found between the arithmetic means of the Family Guidance in Technology Use ( $\mathrm{t}=.091 ; \mathrm{p}>.05)$, Benefits of the Technology ( $\mathrm{t}=.707 ; \mathrm{p}>.05)$, Technology Application Areas ( $\mathrm{t}=1.030 ; \mathrm{p}>.05)$. Harms of the Technology ( $\mathrm{t}=.628 ; \mathrm{p}>.05)$ and the Skill of Using Technologic Devices $(\mathrm{t}=-.002 ; \mathrm{p}>.05)$ dimension. As for the dimension of Suggestions, the difference between the arithmetic means of the groups was found to be statistically significant $(t=2.034 ; \mathrm{p}<.05)$. Upon examining the means in order to determine in favour of which group the difference is, it is seen that the arithmetic mean of the parents who have a daughter $(\overline{\mathbf{X}}=9.83)$ is higher than the arithmetic mean of the parents who have a son $(\overline{\mathbf{X}}=9.49)$. In other words, the difference in question is in favour of the parents who have a daughter.

\subsection{Findings on the Second Sub-objective}

The second sub-objective of the study aims to determine whether the views of the parents on the use of technology in the early childhood period differ by the gender of the parents. Below, there are findings on the second sub-objective in the form of a table. 
Table 2. Independent group t-test results carried out in order to determine whether the sub-scale scores of The Parents' Views on the Use of Technology by Pre-School Period Children Scale differ by the gender of the parent

\begin{tabular}{|c|c|c|c|c|c|c|c|c|}
\hline \multirow[t]{2}{*}{ Sub-dimension } & \multirow{2}{*}{$\begin{array}{l}\text { Gender of } \\
\text { the Parent }\end{array}$} & & \multirow[t]{2}{*}{$\overline{\mathrm{X}}$} & \multirow{2}{*}{$\begin{array}{l}\text { Standart } \\
\text { Deviation }\end{array}$} & \multirow{2}{*}{$\begin{array}{l}\text { Standart } \\
\text { Error } \\
\text { Mean }\end{array}$} & \multicolumn{3}{|l|}{ t-Test } \\
\hline & & & & & & $\mathrm{t}$ & df & $\mathrm{P}$ \\
\hline Guidance & Female & 365 & 19.42 & 2.630 & .138 & & & \\
\hline Technology Use & Male & 70 & 18.60 & 3.071 & .367 & 2.337 & 433 & $.020^{*}$ \\
\hline \multirow[t]{2}{*}{ Benefits of the Technology } & Female & 365 & 15.12 & 4.600 & .241 & & & \\
\hline & Male & 70 & 17.59 & 4.227 & .505 & -4.414 & 433 & $.000^{*}$ \\
\hline Technology & Female & 365 & 7.61 & 3.226 & .169 & & & \\
\hline Areas & Male & 70 & 8.49 & 3.269 & .391 & -2.086 & 433 & $.041 *$ \\
\hline \multirow[t]{2}{*}{ Harms of the Technology } & Female & 365 & 16.64 & 3.508 & .184 & & & \\
\hline & Male & 70 & 15.41 & 3.809 & .455 & 2.631 & 433 & $.009^{*}$ \\
\hline Skill of Using Technologic & Female & 365 & 12.32 & 2.686 & .141 & & & \\
\hline Devices & Male & 70 & 12.49 & 1.991 & .238 & -.617 & 433 & .538 \\
\hline \multirow{2}{*}{ Suggestions } & Female & 365 & 9.58 & 1.869 & .098 & & & \\
\hline & Male & 70 & 10.34 & 1.744 & .208 & -3.322 & 433 & $.001 *$ \\
\hline
\end{tabular}

Upon examining Table 2, it is seen that no statistically significant difference was found between the arithmetic means of the Skill of Using Technologic Devices dimension. ( $\mathrm{t}=-.617 ; \mathrm{p}>.05)$

Statistically significant difference was found between the arithmetic means of the Dimension of Family Guidance in Technology Use $(t=2.337 ; \mathrm{p}<.05)$. Upon examining the means in order to determine in favour of which group the difference is, it is seen that the arithmetic mean of the mothers $(\overline{\mathbf{X}}=19,42)$ is higher than the arithmetic mean of the fathers $(\overline{\mathbf{X}}=18.60)$. In other words, the difference in question is in favour of the mothers.

Statistically significant difference was found between the arithmetic means of the Dimension of Benefits of Technology $(\mathrm{t}=-4.414 ; \mathrm{p}<.05)$. Upon examining the means in order to determine in favour of which group the difference is, it is seen that the arithmetic mean of the fathers $(\overline{\mathbf{X}}=17.59)$ is higher than the arithmetic mean of the mothers $(\overline{\mathbf{X}}=15.12)$. In other words, the difference in question is in favour of the fathers.

Statistically significant difference was found between the arithmetic means of the Dimension of Technology Application Areas $(t=-2.086 ; \mathrm{p}<.05)$. Upon examining the means in order to determine in favour of which group the difference is, it is seen that the arithmetic mean of the fathers $(\overline{\mathbf{X}}=8.49)$ is higher than the arithmetic mean of the mothers $(\overline{\mathbf{X}}=7.61)$. In other words, the difference in question is in favour of the fathers.

Statistically significant difference was found between the arithmetic means of the Dimension of Harms of Technology $(\mathrm{t}=2.631 ; \mathrm{p}<.05)$. Upon examining the means in order to determine in favour of which group the difference is, it is seen that the arithmetic mean of the mothers $(\overline{\mathbf{X}}=16.64)$ is higher than the arithmetic mean of the fathers $(\overline{\mathbf{X}}=15.41)$. In other words, the difference in question is in favour of the mothers.

Statistically significant difference was found between the arithmetic means of the Dimension of Suggestion ( $\mathrm{t}=-3.322$; $\mathrm{p}<.05)$. Upon examining the means in order to determine in favour of which group the difference is, it is seen that the arithmetic mean of the fathers $(\overline{\mathbf{X}}=10.34)$ is higher than the arithmetic mean of the mothers $(\overline{\mathbf{X}}=9.58)$. In other words, the difference in question is in favour of the fathers.

\subsection{Findings on the Third Sub-objective}

The third sub-objective of the study aims to determine whether the views of the parents on the use of technology in the early childhood period differ by the gender of the child. Below, there are findings on the third sub-objective in the form of a table.

Upon examining Table 3, it is seen that no statistically significant difference was found between the arithmetic means of the Family Guidance in Technology Use ( $\mathrm{t}=-.547 ; \mathrm{p}>.05)$, Benefits of the Technology $(\mathrm{t}=.751 ; \mathrm{p}>.05)$, Technology Application Areas ( $\mathrm{t}=.432 ; \mathrm{p}>.05)$, Harms of the Technology ( $\mathrm{t}=-.641 ; \mathrm{p}>.05)$, Skill of Using Technologic Devices $(\mathrm{t}=-1.230 ; \mathrm{p}>.05)$ ve Suggestion $(\mathrm{t}=.813 ; \mathrm{p}>.05)$ dimensions. 
Table 3. Independent group t-test results carried out in order to determine whether the sub-scale scores of The Parents' Views on the Use of Technology by Pre-School Period Children Scale differ by the working status of mother

\begin{tabular}{|c|c|c|c|c|c|c|c|c|}
\hline \multirow[t]{2}{*}{ Sub-dimension } & \multirow{2}{*}{$\begin{array}{l}\text { Working } \\
\text { status } \\
\text { mother }\end{array}$} & \multirow[b]{2}{*}{$\mathrm{N}$} & \multirow[t]{2}{*}{$\overline{\mathrm{X}}$} & \multirow{2}{*}{$\begin{array}{l}\text { Standart } \\
\text { Deviation }\end{array}$} & \multirow{2}{*}{$\begin{array}{l}\text { Standart } \\
\text { Error } \\
\text { Mean }\end{array}$} & \multicolumn{3}{|l|}{$\mathrm{t}$-Test } \\
\hline & & & & & & $\mathrm{t}$ & $\mathrm{df}$ & $\mathrm{P}$ \\
\hline Family Guidance & working & 242 & 19.19 & 2.782 & .179 & & & \\
\hline Technology Use & not working & 221 & 19.33 & 2.896 & .195 & -.547 & 453.216 & .584 \\
\hline Benefits of & working & 242 & 15.72 & 4.540 & .292 & & & \\
\hline Technology & not working & 221 & 15.40 & 4.507 & .303 & .751 & 461 & .453 \\
\hline Technology & working & 242 & 7.79 & 3.341 & .215 & & & \\
\hline Areas & not working & 221 & 7.66 & 3.063 & .206 & .432 & 461 & .666 \\
\hline Harms of the Technology & working & 242 & 16.21 & 3.936 & .253 & & & \\
\hline & not working & 221 & 16.43 & 3.555 & .239 & -.641 & 460.946 & .522 \\
\hline Using & working & 242 & 12.45 & 2.564 & .165 & & & \\
\hline Technologic Devices & not working & 221 & 12.16 & 2.538 & .171 & 1.230 & 461 & .219 \\
\hline Suggestions & working & 242 & 9.70 & 1.691 & .109 & & & \\
\hline & not working & 221 & 9.56 & 1.943 & .131 & .813 & 461 & .417 \\
\hline
\end{tabular}

3.4 Findings on the Fourth Sub-objective

The fourth sub-objective of the study aims to determine whether the views of the parents on the use of technology in the early childhood period differ by the type of the school child attend. Below, there are findings on the fourth sub-objective in the form of a table.

Table 4. Independent group t-test results carried out in order to determine whether the sub-scale scores of The Parents' Views on the Use of Technology by Pre-School Period Children Scale differ by the type of school child attend

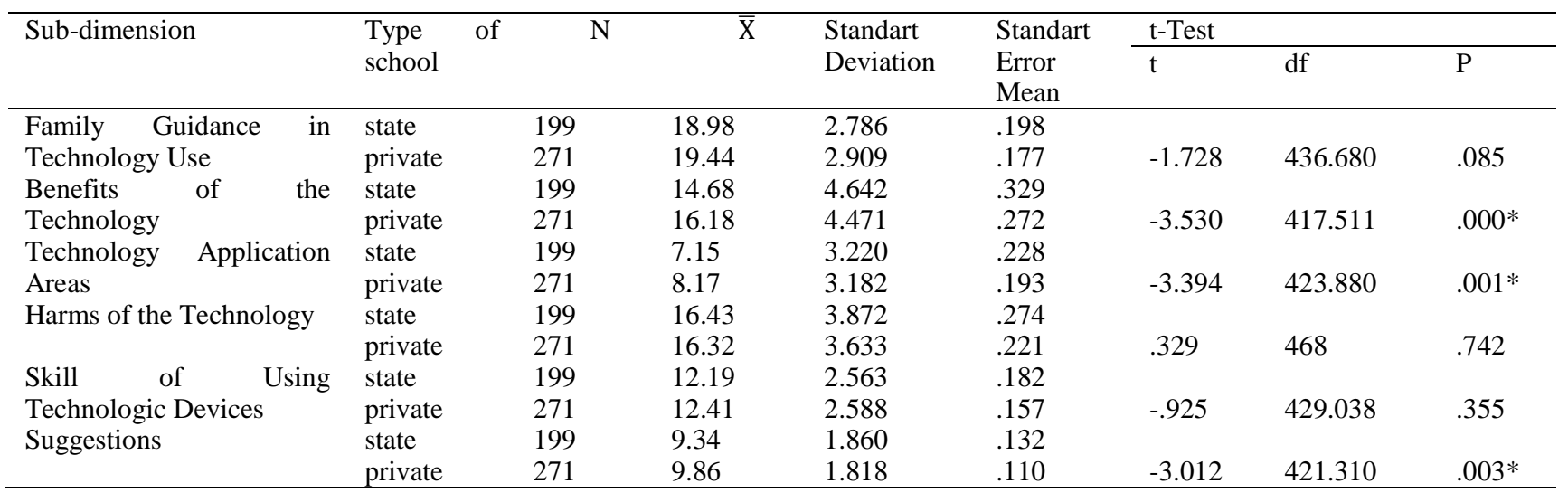

Upon examining Table 4, it is seen that no statistically significant difference was found between the arithmetic means of the Family Guidance in Technology Use ( $\mathrm{t}=-1.728$; $\mathrm{p}>.05)$, Harms of the Technology ( $\mathrm{t}=-.742 ; \mathrm{p}>.05)$, Skill of Using Technologic Devices ( $\mathrm{t}=-.925 ; \mathrm{p}>.05)$ dimensions.

Statistically significant difference was found between the arithmetic means of the dimension of Benefits of Technology $(\mathrm{t}=-3.530 ; \mathrm{p}<.05)$. Upon examining the means in order to determine in favour of which group the difference is, it is seen that the arithmetic mean of the parents whose children attend private pre-school education institution $(\overline{\mathbf{X}}=16.18)$ is higher than the arithmetic mean of the parents whose children attend state pre-school education institution $(\overline{\mathbf{X}}=7.15)$. In other words, the difference in question is in favour of the parents whose children attend private pre-school education institution.

Statistically significant difference was found between the arithmetic means of the dimension of Technology Application Areas ( $\mathrm{t}=-3.394 ; \mathrm{p}<.05)$. Upon examining the means in order to determine in favour of which group the difference is, it is seen that the arithmetic mean of the parents whose children attend private pre-school education institution $(\overline{\mathbf{X}}=8.17)$ is higher than the arithmetic mean of the parents whose children attend state pre-school education institution $(\overline{\mathbf{X}}=14.68)$. In other words, the difference in question is in favour of the parents whose children attend private pre-school education institution.

Statistically significant difference was found between the arithmetic means of the dimension of Suggestion ( $\mathrm{t}=-3.012$; $\mathrm{p}<.05)$. Upon examining the means in order to determine in favour of which group the difference is, it is seen that the arithmetic mean of the parents whose children attend private pre-school education institution $(\overline{\mathbf{X}}=9.86)$ is higher than the arithmetic mean of the parents whose children attend state pre-school education institution $(\overline{\mathbf{X}}=9.34)$. In other words, the difference in question is in favour of the parents whose children attend private pre-school education institution. 


\subsection{Findings on the Fifth Sub-objective}

The fifth sub-objective of the study aims to determine whether the views of the parents on the use of technology in the early childhood period differ by the age of the children. Below, there are findings on the fifth sub-objective in the form of tables.

Table 5. Results of the One-Way Variance Analysis (ANOVA) performed in order to determine whether the sub-scale scores of the Parents' Views on the Use of Technology by Pre-school Children Scale differ by the age of the children

\begin{tabular}{|c|c|c|c|c|c|c|c|c|c|c|}
\hline & & & & $\overline{\mathrm{X}}$ & $\overline{\text { and }}$ & & & & & Values \\
\hline Sub-Dimension & Group & $\mathrm{N}$ & $\overline{\bar{X}}$ & sd & $\begin{array}{l}\text { Source of } \\
\text { the Variance }\end{array}$ & $\begin{array}{l}\text { Sum of } \\
\text { Squares }\end{array}$ & $d f$ & $\begin{array}{l}\text { Mean } \\
\text { Square }\end{array}$ & $F$ & $P$ \\
\hline Family Guidance & 4 years & 57 & 18.26 & 3.677 & Intergroups & 68.302 & 2 & 34.151 & 4.293 & $.014^{*}$ \\
\hline in Technology & 5 years & 182 & 19.52 & 2.755 & Intragroup & 3722.577 & 468 & 7.954 & & \\
\hline Use & $\begin{array}{l}6 \text { years } \\
\text { Total }\end{array}$ & $\begin{array}{l}232 \\
471\end{array}$ & $\begin{array}{l}19.31 \\
19.26\end{array}$ & $\begin{array}{l}2.625 \\
2.840\end{array}$ & Total & 3790.879 & 470 & & & \\
\hline Benefits of the & 4 years & 57 & 14.56 & 14.560 & Intergroups & 117.958 & 2 & 58.979 & 2.814 & .061 \\
\hline Technology & $\begin{array}{l}5 \text { years } \\
6 \text { years } \\
\text { Total }\end{array}$ & $\begin{array}{l}182 \\
232 \\
471\end{array}$ & $\begin{array}{l}15.30 \\
16.02 \\
15.56\end{array}$ & $\begin{array}{l}15.300 \\
16.020 \\
15.560\end{array}$ & $\begin{array}{l}\text { Intragroup } \\
\text { Total }\end{array}$ & $\begin{array}{l}9809.944 \\
9927.902\end{array}$ & $\begin{array}{l}468 \\
470\end{array}$ & 20.961 & & \\
\hline Technology & 4 years & 57 & 8.35 & 3.508 & Intergroups & 79.061 & 2 & 39.531 & 3.838 & $.022 *$ \\
\hline Application Areas & $\begin{array}{l}5 \text { years } \\
6 \text { years } \\
\text { Total }\end{array}$ & $\begin{array}{l}182 \\
232 \\
471\end{array}$ & $\begin{array}{l}7.26 \\
8.01 \\
7.76\end{array}$ & $\begin{array}{l}3.277 \\
3.078 \\
3.229\end{array}$ & $\begin{array}{l}\text { Intragroup } \\
\text { Total }\end{array}$ & $\begin{array}{l}4820.306 \\
4899.367\end{array}$ & $\begin{array}{l}468 \\
470\end{array}$ & 10.300 & & \\
\hline Harms of the & 4 years & 57 & 15.95 & 4.274 & Intergroups & 11.992 & 2 & 5.996 & .432 & 649 \\
\hline Technology & $\begin{array}{l}5 \text { years } \\
6 \text { years } \\
\text { Total }\end{array}$ & $\begin{array}{l}182 \\
232 \\
471\end{array}$ & $\begin{array}{l}16.46 \\
16.41 \\
16.37\end{array}$ & $\begin{array}{l}3.843 \\
3.481 \\
3.721\end{array}$ & $\begin{array}{l}\text { Intragroup } \\
\text { Total }\end{array}$ & $\begin{array}{l}6495.987 \\
6507.979\end{array}$ & $\begin{array}{l}468 \\
470\end{array}$ & 13.880 & & \\
\hline Skills of Using & 4 years & 57 & 11.72 & 2.744 & Intergroups & 27.098 & 2 & 13.549 & 2.070 & .127 \\
\hline Technologic & 5 years & 182 & 12.30 & 2.580 & Intragroup & 3063.849 & 468 & 6.547 & & \\
\hline Devices & $\begin{array}{l}6 \text { years } \\
\text { Total }\end{array}$ & $\begin{array}{l}232 \\
471\end{array}$ & $\begin{array}{l}12.49 \\
12.32\end{array}$ & $\begin{array}{l}2.495 \\
2.564\end{array}$ & Total & 3090.947 & 470 & & & \\
\hline Suggestions & $\begin{array}{l}4 \text { years } \\
5 \text { years } \\
6 \text { years } \\
\text { Total }\end{array}$ & $\begin{array}{l}57 \\
182 \\
232 \\
471\end{array}$ & $\begin{array}{l}9.39 \\
9.49 \\
9.85 \\
9.65\end{array}$ & $\begin{array}{l}1.497 \\
1.780 \\
1.976 \\
1.856\end{array}$ & $\begin{array}{l}\text { Intergroups } \\
\text { Intragroup } \\
\text { Total }\end{array}$ & $\begin{array}{l}17.884 \\
1600.707 \\
1618.590\end{array}$ & $\begin{array}{l}2 \\
468 \\
470\end{array}$ & $\begin{array}{l}8.942 \\
3.420\end{array}$ & 2.614 & .074 \\
\hline
\end{tabular}

As is seen in Table 5, the difference between the arithmetic averages of the groups was found to be insignificant in the sub-dimensions of the Benefits of the Technology ( $F=2.814 ; p>.05)$, Harms of the Technology ( $F=.432 ; p>.05)$, Skills of Using Technologic Devices ( $F=2.070 ; p>.05)$ and Suggestions $(F=2.614 ; p>.05)$.

The significance between the arithmetic means of the groups was found significant in the sub-dimensions of Family Guidance in Technology Use ( $\mathrm{F}=4.293 ; \mathrm{p}<.05)$ and Technology Application Areas ( $\mathrm{F}=3.838 ; \mathrm{p}<.05)$. Complementary analyses were initialized following this result. The homogeneity of the variances was checked first when determining which comparison analysis to use. It was found out that the variance is not homogenous in the sub-dimension of the Family Guidance in Technology Use $(\mathrm{p}<.05)$, and thus the Tamhane's analysis was applied. As for the sub-dimension of the Technology Application Areas ( $>$ >.05), the variance was found to be homogeneous and hence the Scheffe's analysis was applied. The comparative results of the Tamhane's and Scheffe's analyses are tabulated below.

As is seen in Table 6. the difference between the arithmetic averages of the groups could not be found significant as a result of the Tamhane's T2 and Scheffe's test carried out in order to determine between which groups the scores taken from the sub-dimensions of family guidance in technology use and technology application areas vary by the children's age $(p>.05)$. 
Table 6. The results of the Tamhane's T2 and Scheffe's tests carried out in order to determine between which groups the scores taken from the sub-dimensions of family guidance in technology use and technology application areas vary by the age of the children

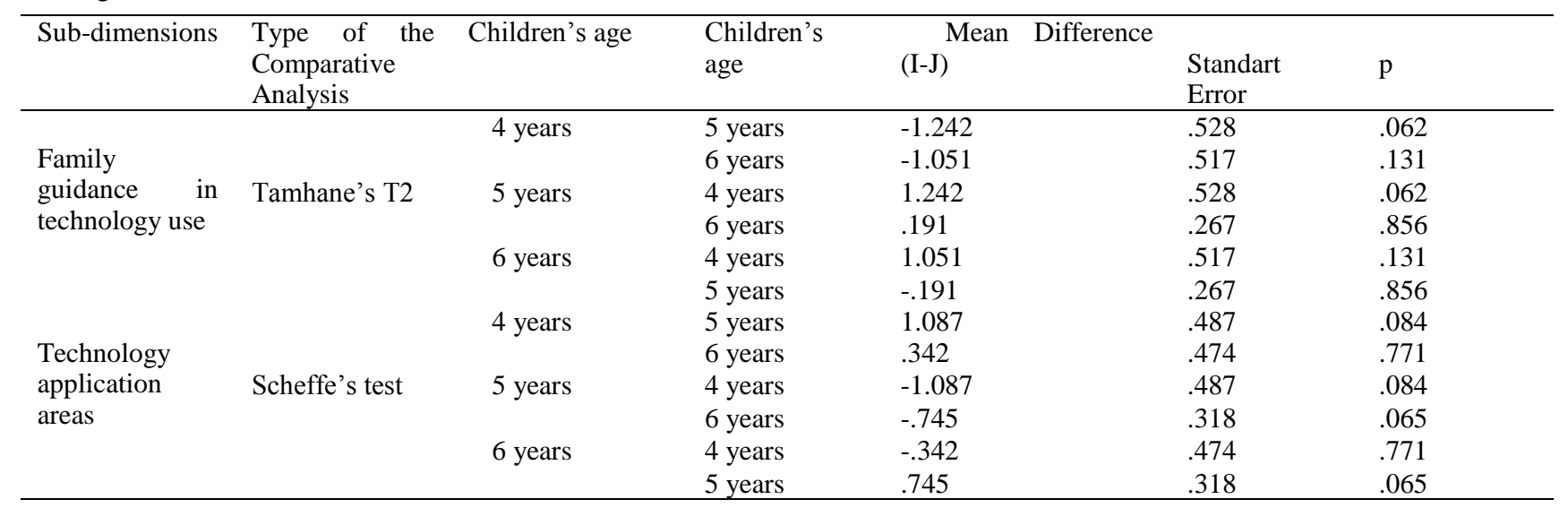

3.6 Findings on the Sixth Sub-objective

The sixth sub-objective of the study aims to determine whether the views of the parents on the use of technology in the early childhood period differ by the number of the children parents have been shown below. There are findings on the sixth sub-objective in the form of a table.

Table 7. Results of the Kruskal Wallis-H Test carried out in order to determine whether the sub-scale scores of the parents' views on the use of technology by pre-school children scale differ by the number of children parents have

\begin{tabular}{|c|c|c|c|c|c|c|}
\hline Sub-dimension & $\begin{array}{l}\text { Number of children } \\
\text { parents have }\end{array}$ & $\mathrm{N}$ & Mean rank & SD & $\mathrm{X}^{2}$ & $\mathrm{P}$ \\
\hline Family & 1 & 177 & 233.82 & & & \\
\hline Guidance in & 2 & 236 & 241.51 & & & \\
\hline Technology & 3 & 50 & 217.23 & 3 & 2.748 & .432 \\
\hline \multirow[t]{2}{*}{ Use } & 4 & 10 & 285.85 & & & \\
\hline & Total & 473 & & & & \\
\hline Benefits of the & 1 & 177 & 238.33 & & & \\
\hline \multirow[t]{4}{*}{ Technology } & 2 & 236 & 234.07 & & & \\
\hline & 3 & 50 & 246.54 & 3 & .373 & .946 \\
\hline & 4 & 10 & 234.95 & & & \\
\hline & Total & 473 & & & & \\
\hline Technology & 1 & 177 & 232.67 & & & \\
\hline Application & 2 & 236 & 232.68 & & & \\
\hline \multirow[t]{3}{*}{ Areas } & 3 & 50 & 256.74 & 3 & 4.995 & .172 \\
\hline & 4 & 10 & 317.00 & & & \\
\hline & Total & 473 & & & & \\
\hline Harms of the & 1 & 177 & 238.27 & & & \\
\hline \multirow{4}{*}{ Technology } & 2 & 236 & 240.05 & & & \\
\hline & 3 & 50 & 205.88 & 3 & 4.847 & .183 \\
\hline & 4 & 10 & 298.05 & & & \\
\hline & Total & 473 & & & & \\
\hline Skills of Using & 1 & 177 & 230.40 & & & \\
\hline Technologic & 2 & 236 & 233.83 & & & \\
\hline \multirow[t]{3}{*}{ Devices } & 3 & 50 & 275.62 & 3 & 4.606 & .203 \\
\hline & 4 & 10 & 235.45 & & & \\
\hline & Total & 473 & & & & \\
\hline \multirow{5}{*}{ Suggestions } & 1 & 177 & 231.30 & & & \\
\hline & 2 & 236 & 243.80 & & & \\
\hline & 3 & 50 & 232.55 & 3 & 1.758 & .624 \\
\hline & 4 & 10 & 199.70 & & & \\
\hline & Total & 473 & & & & \\
\hline
\end{tabular}

Upon examining Table 7, it is seen that no statistically significant difference was found between the scores of the Family Guidance in Technology Use $\left(X^{2}=2.748 ; p>.05\right)$, Benefits of the Technology $\left(X^{2}=.373 ; p>.05\right)$, Technology Application Areas $\left(X^{2}=4.995 ; p>.05\right)$, Harms of the Technology $\left(X^{2}=4.847 ; p>.05\right)$, Skill of Using Technologic Devices $\left(X^{2}=4.606\right.$; $\mathrm{p}>.05)$ and Suggestions $\left(X^{2}=1.758 ; \mathrm{p}>.05\right)$ dimensions. 


\subsection{Findings on the Seventh Sub-objective}

The seventh sub-objective of the study aims to determine whether the views of the parents on the use of technology in the early childhood period differ by the level of income. Below, there are findings on the seventh sub-objective in the form of tables.

Table 8. Results of the Kruskal Wallis-H Test carried out in order to determine whether the sub-scale scores of the parents' views on the use of technology by pre-school children scale differ by the number of children parents have

\begin{tabular}{|c|c|c|c|c|c|c|}
\hline Sub-dimension & Income level & $\mathrm{N}$ & Mean rank & SD & $\mathrm{X}^{2}$ & $\mathrm{P}$ \\
\hline Family Guidance & low & 27 & 185.37 & & & \\
\hline \multirow{3}{*}{ in Technology Use } & medium & 384 & 217.08 & & & \\
\hline & high & 22 & 254.39 & 3 & 3.789 & .150 \\
\hline & Total & 433 & & & & \\
\hline Benefits of the & low & 27 & 242.11 & & & \\
\hline \multirow[t]{3}{*}{ Technology } & medium & 384 & 214.96 & & & \\
\hline & high & 22 & 221.86 & 3 & 1.229 & .541 \\
\hline & Total & 433 & & & & \\
\hline Technology & low & 27 & 220.17 & & & \\
\hline \multirow[t]{3}{*}{ Application Areas } & medium & 384 & 216.69 & & & \\
\hline & high & 22 & 218.52 & 3 & .023 & .988 \\
\hline & Total & 433 & & & & \\
\hline Harms of the & low & 27 & 181.65 & & & \\
\hline \multirow[t]{3}{*}{ Technology } & medium & 384 & 216.20 & & & \\
\hline & high & 22 & 274.32 & 3 & 6.959 & $.031 *$ \\
\hline & Total & 433 & & & & \\
\hline Skills of Using & low & 27 & 285.20 & & & \\
\hline Technologic & medium & 384 & 210.48 & & & \\
\hline \multirow[t]{2}{*}{ Devices } & high & 22 & 247.02 & 3 & 10.499 & $.005 *$ \\
\hline & Total & 433 & & & & \\
\hline \multirow[t]{4}{*}{ Suggestions } & low & 27 & 220.28 & & & \\
\hline & medium & 384 & 214.57 & & & \\
\hline & high & 22 & 255.48 & 3 & 2.335 & .311 \\
\hline & Total & 433 & & & & \\
\hline
\end{tabular}

Upon examining Table 8, it is seen that no statistically significant difference was found between the scores of the Family Guidance in Technology Use $\left(X^{2}=3.789 ; p>.05\right)$, Benefits of the Technology $\left(X^{2}=1.229 ; p>.05\right)$, Technology Application Areas $\left(X^{2}=.023 ; p>.05\right)$ and Suggestions $\left(X^{2}=2.335 ; p>.05\right)$ dimension.

It is seen that statistically significant difference was found between the scores of the Harms of the Technology $\left(X^{2}=6.959\right.$; $\mathrm{p}<.05)$ and Skill of Using Technologic Devices $\left(X^{2}=10.499 ; \mathrm{p}<.05\right)$.

After that, Mann Whitney U Test was carried out in order to determine between which groups the scores taken by the parents from the sub-dimensions of the harms of the technology and skill of using technologic devices differ by the level of income. Below, there are findings in the form of a table.

Table 9. Results of the Mann-Whitney U Test carried out in order to determine between which groups the scores taken by the parents from the sub-dimensions of the harms of the technology and skills of using technologic devices differ by the level of income

\begin{tabular}{|c|c|c|c|c|c|c|c|}
\hline Sub-dimension & Level of income & $\mathrm{N}$ & Mean rank & Sum of ranks & $\mathrm{Z}$ & $\mathrm{U}$ & $\mathrm{P}$ \\
\hline $\begin{array}{l}\text { Harms of the } \\
\text { technology }\end{array}$ & $\begin{array}{l}\text { low } \\
\text { high } \\
\text { total }\end{array}$ & $\begin{array}{l}27 \\
22 \\
49\end{array}$ & $\begin{array}{l}20.39 \\
30.66\end{array}$ & $\begin{array}{l}1248.50 \\
77.50\end{array}$ & -2.559 & 172.500 & $.011 *$ \\
\hline $\begin{array}{l}\text { Harms of the } \\
\text { technology }\end{array}$ & $\begin{array}{l}\text { medium } \\
\text { high } \\
\text { Total }\end{array}$ & $\begin{array}{l}384 \\
22 \\
406\end{array}$ & $\begin{array}{l}200.54 \\
255.16\end{array}$ & $\begin{array}{l}77007.50 \\
5613.50\end{array}$ & -2.151 & 3087.500 & $.031 *$ \\
\hline $\begin{array}{l}\text { Skills of using } \\
\text { technologic } \\
\text { devices }\end{array}$ & $\begin{array}{l}\text { Low } \\
\text { medium } \\
\text { Total }\end{array}$ & $\begin{array}{l}27 \\
384 \\
411\end{array}$ & $\begin{array}{l}272.11 \\
201.35\end{array}$ & $\begin{array}{l}7347.00 \\
77319.00\end{array}$ & -3.018 & 3399.000 & $.003^{*}$ \\
\hline
\end{tabular}

Upon examining Table 9, the difference between the groups in terms of the scores taken by parents in the sub-dimension of the Harms of the Technology was found to be significant ( $p<.05)$. Accordingly, when the averages of order are investigated, it is seen that parents with a high level of income (mean rank $=30.66$ ) obtained higher scores from the sub-dimension of the Harms of the Technology when compared to the parents with a low level of income (mean rank = 20.39). It is seen that parents with a high level of income have higher scores in the sub-dimension of the Harms of the Technology (mean rank $=255.16)$ when compared to the parents with a middle level of income (mean rank $=200.54)$. 
The difference between the groups was found to be significant in the scores taken by the parents from the sub-dimension of the Skills of Using Technologic Devices ( $\mathrm{p}<.05)$. Accordingly, upon looking at the averages of order, it is seen that parents with a low level of income (mean rank $=272.11$ ) have higher scores from the sub-dimension of the Skills of Using Technologic Devices when compared to the parents with a middle level of income (mean rank $=201.35$ ).

\section{Results and Discussion}

In this study, it was determined that the views of parents on the use of technology in the early childhood period differ significantly by the children's gender in the sub-dimension of suggestions.

Accordingly, the scores taken by the parents with daughters in the sub-dimension of suggestions are higher than of those with sons. This may be explained by the fact that parents in Turkey are more protective of their daughters.

According to another result obtained from this study, the parents' views on the use of technology in the early childhood period differ significantly by the gender of parents in terms of the family guidance in technology use, benefits of the technology, technology application areas, harms of the technology and suggestions dimension. Accordingly, the scores taken by mothers in the sub-dimension of the family guidance in technology use and the harms of the technology are higher than the scores of fathers. In the study carried out by Kilınç (2015), parents' views on the use of technology by students in the pre-school period were examined by the gender variable, and it was found that male parents have more positive views on the use of technology in the education of pre-school children when compared to female parents in the dimension of technology application areas. In the study carried out by Liau, Khoo and Ang (2008) in Singapore, it was found out that the views of female parents on the use of technology in the education of pre-school children are more positive than those of male parents. This can be explained by the fact that the children of mothers are more sensitive about the use of technology in certain aspects.

According to another result obtained from the study, parents' views on the use of technology in the early childhood period differ significantly by the working status of the mother, the age of the child and the number of children the parents have. This may be explained by the fact that the workload in working conditions is similar to the workload regarding the roles of parenthood at home, the children are all in the pre-school period despite their age differences and having similar features and the educational and developmental sensitivity shown by parents towards each child is equal no matter what the number of children is.

According to another result of this study, the parents' views on the use of technology in the early childhood period differ by the benefits of the technology, technology application areas and suggestions dimension by the type of the school the child attends. Accordingly, the scores taken by the parents whose children attend private pre-school education institutions are higher than the scores taken by the parents whose children attend state pre-school education institutions in the dimension of the benefits of the technology, technology application areas, and suggestions. This can be explained by the fact that private pre-school education institutions have more opportunities than state pre-schools in terms of using technology in education. Indeed, in a study carried out by Judge, Puckett, and Çabuk (2004), it was expressed that private schools are richer than state schools in terms of ICT and the technologic programs used in education. In another study carried out by Waxman (1994), it was expressed that the use of technology at state schools, especially at those schools to which poor families send their children, is quite limited. As distinct from this result, in the study carried out by Kılınç (2015), it was found out that the views of the parents who send their children to state pre-schools on the benefits of using technology in pre-school education are more positive than of those parents who send their children to private pre-schools.

According to another result obtained from this study, the parents' views on the use of technology in the early childhood period differ significantly by the level of income of the family in the dimensions of the skills of using technologic devices and the harms of the technology. Accordingly, the scores taken by the parents with a low level of income in the dimension of the skills of using technologic devices are higher than the scores taken by the parents who have a middle level of income. In the dimension of the harms of the technology, the scores taken by the parents with a high and low level of income are higher than the scores taken by the parents with a low level of income. This can be explained by the fact that the technological facilities that parents provide to their children increase as the level of income increases, and they experience the harm that the use of these technologic devices can give to the child.

\section{References}

Akkoyunlu, B., \& Tuğrul, B. (2002). Okul öncesi çocukların ev yaşantısındaki teknolojik etkileşimlerinin bilgisayar okuryazarlığı becerileri üzerindeki etkisi. Hacettepe Üniversitesi Eğitim Fakültesi Dergisi, 23, 12-21.

Akpınar, Y. (2005). Bilgisayar destekli eğitimde uygulamalar. Ankara: Anı Yayıncılık.

Arı, M., \& Bayhan, P. (2003). Okul öncesi dönemde bilgisayar destekli eğitim. Ankara: Epsilon Yayınları. 
Arrowood, D., \& Overall, T. (2004). Using technology to motivate children to write: Changing attitudes in children and preservice teachers. In R. Ferdig et al. (Eds.), Proceedings of Society for Information Technology and Teacher Education International Conference (pp. 4985-4987). Chesapeake, VA: AACE. http://www.editlib.org/p/13221

Aslanidou, S., \& Menexes, G. (2008). Youth and the internet: Uses and practices in the home. Computers and Education, 51(3), 1375-1391. http://dx.doi.org/10.1016/j.compedu.2007.12.003

Ayvac1, H. S., \& Devecioğlu, Y. (2010). Computer-assisted instruction to teach concepts in pre-school education. Procedia Social and Behavioral Sciences, 2, 2083-2087. http://dx.doi.org/10.1016/j.sbspro.2010.03.285

Bartlett, J., \& Miller, C. (2011). Truth, lies and the Internet a report into young people's digital fluency. Demos: London http://www.demos.co.uk/files/Truth_-_web.pdf

Bolgan, N. (2006). Temahefte om IKT i barnehagen. Oslo: Ministry of Research and Education

Bütün-Ayhan, A., \& Aral, N. (2005). Bilimsel araştırma ve incelemeler. Ankara: A.Ü. Ev Ekonomisi Yüksekokulu Yayın No: 10.

Büyüköztürk, Ş. (2011). Sosyal bilimler için veri analizi el kitabı: İstatistik, araştırma deseni, SPSS uygulamaları ve yorum . Ankara: Pegem Akademi.

Çankaya, Ö. (2012). Bilgisayar oyunlarının okul öncesi eğitiminde kullanılmasının bazı matematiksel kavramların ögretimi üzerine etkisi, (Yayımlanmamış yüksek lisans tezi), Atatürk Üniversitesi Eğitim Bilimleri Enstitüsü, Erzurum, Türkiye.

Chang, C. (2010). Internet safety survey: Who will protect the children. Berkeley Tech. LJ, $25,501$. http://scholarship.law.berkeley.edu/cgi/viewcontent.cgi?article=1835\&context=btlj

Chung, Y., \& Walsh, D. J. (2006). Constructing a joint story-writing space: The dynamics of young children's collaboration at computers. Early Education and Development, 17(3), 337-420. http://dx.doi.org/10.1207/s15566935eed1703_4

Clements, D. H., \& Sarama, J. (2003). Young children and technology: What does the research say? Young Children, 58(6), 34-40.

Cordes, C., \& Miller, E. (2000). Fool's gold: A critical look at computers in childhood. Alliance for Childhood. http://files.eric.ed.gov/fulltext/ED445803.pdf

Couse, L. J., \& Chen, D. W. (2010). A tablet computer for young children? Exploring its viability for early childhood education. Journal of Research on Technology in Education, 43(1), 75-96. http://dx.doi.org/10.1080/15391523.2010.10782562

Demir, N., \& Kabadayı, A. (2008). Erken yaşta renk kavramının kazandırılmasında bilgisayar destekli ve geleneksel öğretim yöntemlerinin karşılaştırılması. Uluslararası İnsan Bilimleri Dergisi, 5(1), 1-18.

Emir, Ö. M. (2011). Çocuk programlarının 60-72 aylı çocuk davranışlarına etkileri, (Yayımlanmamış yüksek lisans tezi), Afyon Kocatepe Üniversitesi, Sosyal Bilimler Enstitüsü, Afyon.

Erdoğan, İ., (2009). Okul öncesi dönemde satranç öğretiminde geleneksel ve bilgisayar destekli öğretim yöntemlerinin karşılaştırılması, (Yayımlanmamış yüksek lisans tezi,) Selçuk Üniversitesi Sosyal Bilimler Enstitüsü, Konya, Türkiye.

Gasser, U., Maclay, C. M., \& Palfrey, J. (2010). Working towards a deeper understanding of digital safety for children and young people in developing nations (June 21, 2010). Berkman Center Research Publication No. 2010-7; Harvard Public Law Working Paper No. 10-36. http://papers.ssrn.com/sol3/papers.cfm?abstract_id=1628276

Gimbert, B., \& Cristol, D. (2004). Teaching curriculum with technology: Enhancing children's technological competence during early childhood. Early Childhood Education Journal, 31(3), 207-216. http://dx.doi.org/10.1023/B:ECEJ.0000012315.64687.ee

Göğebakan, Ş. (2011). Çocuğunu okul öncesi eğitim kurumuna gönderen (6 yaş) annelerin okul öncesi eğitime ilişsin görüşlerinin bazı demografik özelliklere göre incelenmesi (Yayınlanmamış yüksek lisans tezi). İnönü Üniversitesi, eğitim Bilimleri Enstitüsü. Malatya, Türkiye.

Hansen, L. I. (2009). “We just click!” ICT from preschool children's perspectives. (Unpublished Master Thesis). Oslo University College, Oslo.

Holloway, D., Green, L., \& Livingstone, S. (2013). Zero to eight. young children and their internet use. LSE, London: EU Kids Online. http://eprints.Ise.ac.uk/52630/1/Zero_to_eight.pdf 
İlhan, A. Ş. (2004). Öğretim teknolojileri ve materyal destekli yabancı dil (İngilizce) öğretiminin, ilköğretim okul öncesi eğitimi anasınıfi ögrencilerinin ögrrenme ve hatırlama düzeyleri üzerindeki etkisi (Yayınlanmamış Yüksek Lisans Terzi), Muğla Üniversitesi, Muğla, Türkiye.

Judge, S., Puckett, K., \& Çabuk, B. (2004). Digital equity: New findings from the early childhood longitudinal study. Journal of Research on Technology in Education, 36(4), 383-396. http://dx.doi.org/10.1080/15391523.2004.10782421

Karasar, N. (2012). Bilimsel araştırma yöntemi. Ankara: Nobel Yayıncılık.

Kenanoğlu, R., \& Kahyaoğlu, M. (2011). Okul öncesi öğrencilerin İnternet kullanımı ile bilişsel, duyuşsal ve sosyal davranışları arasındaki ilişki. 5th International Computer ve Instructional Technologies Symposium, Furat Üniversitesi, Elazı̆̆.

Kılınç, S. (2015). Okul öncesi çağındaki çocukların teknoloji kullanımı hakkında ebeveyn görüşlerinin incelenmesi, (Yayınlanmamış yüksek lisans tezi), Dumlupınar Üniversitesi, Eğitim Bilimleri Enstitüsü, Kütahya, Türkiye.

Kol, S. (2012). Bilgisayar destekli öğretimin (BDÖ) altı yaş çocuklarına zaman ve mekân kavramlarını kazandırmaya etkisi, (Yayımlanmamış doktora tezi), Selçuk Üniversitesi, Sosyal Bilimler Enstitüsü, Konya, Türkiye.

Kucirkova, N., Messer, D., Sheehy, K., \& Panadero, C. F. (2014). Children's engagement with educational iPad apps: Insights from a Spanish classroom. Computers \& Education, 71, 175-184. http://dx.doi.org/10.1016/j.compedu.2013.10.003

Küçükoğlu, B. (2013). Okul öncesi eğitime yönelik bilgisayar destekli öğretim tasarımı (Yayınlanmamış yüksek lisans tezi). Bahçeşehir Üniversitesi Fen Bilimleri Enstitüsü, İstanbul, Türkiye.

Kumtepe, A. T. (2006). The Effects of computers on kindergarten children's social skills. The Turkish Online Journal of Educational Technology, 5(4), Article 7. http://tojet.net/articles/v5i4/547.pdf

Liau, A. K., Khoo, A., \& Ang, P. H. (2008). Parental awareness and monitoring of adolescent internet use. Current Psychology, 27(4), 217-233. http://dx.doi.org/10.1007/s12144-008-9038-6

Marsh, J., Brooks, G., Hughes, J., Ritchie, L., Roberts, S., \& Wright, K. (2005). Digital Beginnings: Young children's use of popular culture, media and new technologies. Sheffield: University of Sheffield.

Matthews, J., \& Jessel, J. (1993). Very young children use electronic paint: A study of the beginnings of drawing with traditional media and computer paintbox. Visual Arts Research, 19(1), 47-62.

MEB [Milli Eğitim Bakanlı̆̆ı]. (2013). Okul Öncesi eğitim Programi. http://ttkb.meb.gov.tr/program2.aspx/program2.aspx?islem=1\&kno=202

Mishra, P. K., \& Joseph, A. (2012). Early childhood care \& education: An ICT perspective. Information Technologies and Learning Tools, 27. ISSN 2076-8184. http://dx.doi.org/10.5958/j.0975-6884.6.2.014

O'Hara, M. (2008). Young children, learning and ICT: A case study in the UK maintained sector. Technology, Pedogogy and Education, 17(1), 29-40. http://dx.doi.org/10.1080/14759390701847443

OECD [The Organisation for Economic Co-operation and Development] (2011). The protection of children online: Risks faced by children online and policies to protect them. OECD Digital Economy Papers, No. 179, OECD Publishing, Paris. http://dx.doi.org/10.1787/5kgcjf71pl28-en

Özmert, E. (2005). Erken çocukluk gelişiminin desteklenmesi-I. Çocuk Sağlığı ve Hastalıkları Dergisi, 48:179-195.

Plowman, L., \& Stephen, C. (2005). Children, play and computers in pre-school education. British Journal of Educational Technology, 36(2), 145-157. http://dx.doi.org/10.1111/j.1467-8535.2005.00449.x

Plowman, L., McPake, J., \& Stephen, C. (2010). The technologisation of childhood? Young children and technology in the home. Children and Society, 24(1), 63-74. http://dx.doi.org/10.1111/j.1099-0860.2008.00180.x

Rasanen, P., Salminen, J., Wilson, A. J., Aunio, P., \& Dehaene, S. (2009). Computer-assisted intervention for children with low numeracy skills. Cognitive Development, 24, 450-472. http://dx.doi.org/10.1016/j.cogdev.2009.09.003

Rideout, V. J., Vandewater, E. A., \& Wartella, E. A. (2003). Zero to six. California: Kaiser Family Foundation.

RTÜK [Radyo ve Televizyon Üst Kurulu]. (2013). 1. Türkiye çocuk ve medya kongresi Türkiye'de çocukların medya kullanma alışkanlıkları araştırması. İstanbul: Çocuk Vakfi Yayınları.

Şen, M. (2012). Okul öncesi dönemde teknoloji kullanımı. İçinde N. Avc1 ve M. Toran (Ed.), Okul öncesi eğitime giriş (289-299). Ankara: Eğiten Kitap. (ISBN: 978-605-5472-72-6).

Siraj-Blatchford, I., \& Siraj-Blatchford, J. (2003). More than computers: Information and communication technology in 
the early years. London: The British Association for Early Childhood Education.

Sivin-Kachala, J., \& Bialo, E. R. (2000). Research report on the effectiveness of technology in schools. Washington, DC: Software and Information Industry Association.

Talley, S., Lance, D. F., \& Lee, T. R. (1997). Children, storybooks and computers. Reading Horizons, 38(3), 116-128.

Tekcan, A. (2009). Bilgisayar destekli okul öncesi eğitimde milli öğelerin kullanımı ve bir etkileşimli eğitim tasarımı (Yayınlanmamış Yüksek Lisans Tezi). Sakarya Üniversitesi Sosyal Bilimler Enstitüsü, Sakarya, Türkiye.

Trepanier-Street, M. L., Hong, S. B., \& Bauer, J. C. (2001). Using technology in Reggio-inspired long-term projects. Early Childhood Education Journal, 28(3), 181-188. http://dx.doi.org/10.1023/A:1026547302846

Valcke, M., Bonte, S., De Wever, B., \& Rots (2010). Internet parenting styles and the impact on internet use of primary school children. Computers \& Education, 55(2), 454-464. http://dx.doi.org/10.1016/j.compedu.2010.02.009

Veenstra, B., Van Geert, P. L. C., \& Van der Meulen, B. F. (2010). Computers versus human-based support: Effect on computer game performances in (in)effectively learning pre-schoolers. Educational \& Child Psychology, 27(4), 56-72.

Waxman, H. C. (1994). Differences among urban, suburban, and rural high schools on technology use in science and mathematics. In J. Willis et al. (Eds.), Proceedings of Society for Information Technology and Teacher Education International Conference (pp. 589-592). Chesapeake, VA: Association for the Advancement of Computing in Education (AACE). 